\title{
Pengaruh Effleurage Massage terhadap Nyeri Persalinan Kala I Fase Aktif di Praktik Mandiri Bidan Nuriman Rafida dan Praktik Mandiri Bidan Latifah Kota Jambi Tahun 2019
}

\author{
Herinawati ${ }^{1}$, Titik Hindriati ${ }^{2}$, Astrid Novilda ${ }^{3}$ \\ 1,2,3Poltekkes Jambi \\ JI. DR. GA. Siwabessy No.9 Buluran Kenali Telanaipura Jambi Kodepos. 36125 \\ Correspondence email: herinawati_burhanuddin@yahoo.com
}

\begin{abstract}
One of the complaints that is often felt by mothers is pain during contractions and effleurage massage is one technique that can cause the effects of distraction and relaxion, thus helping the mother become more relaxed, creating a feeling of comfort, and pain response will decrease. The purpose of this study was to determine the effect of effleurage massage on labor pain in the first stage in the practice of Midwife Nuriman Rafida and Latifah Midwife Practice in 2019. The sampling technique used a total sampling technique that was as many as 30 women who had labor pain. The level of pain during the active phase I before the massage effleurage: 16 (53.0\%) respondents experienced moderate pain levels and 14 (47.0\%) respondents experienced severe pain levels, and none experienced mild pain. The level of pain during the first active phase after effleurage massage: most (57.0\%) respondents felt mild pain, still some (33\%) respondents who felt moderate pain, and only a small percentage (10\%) of respondents felt severe pain. The results of the Wilcoxon test showed that giving effleurage massage had a significant effect on pain when I was active phase $P$ value was $0.001(p<0.05)$.
\end{abstract}

Keywords: Effleurage Massage; Labor Pain; Mother Giving Birth

\section{PENDAHULUAN}

Persalinan merupakan proses pengeluaran janin yang terjadi pada kehamilan cukup bulan 37-42 minggu, dimana janin dilahirkan secara spontan dengan presentasi belakang kepala yang berlangsung dalam 18 jam, tanpa komplikasi baik pada ibu maupun pada janin (Indriyani, dkk, 2016:21).

Penelitian di Amerika serikat $70 \%$ sampai $80 \%$ wanita yang melahirkan mengharapkan persalinan berlangsung tanpa rasa nyeri. Berbagai cara dilakukan agar ibu melahirkan tidak selalu merasa sakit dan merasakan nyaman. Saat ini di Negara berkembang $20 \%$ hingga $50 \%$ persalinan di rumah sakit besar dilakukan dengan section caesaria disebabkan para ibu hendak bersalin lebih memilih operasi yang relative tidak nyeri sedangkan di Brazil angka ini mencapai lebih dari $50 \%$ dari angka kelahiran di suatu rumah sakit yang merupakan presentase tertinggi di seluruh dunia. Nyeri yang terjadi dapat mempengaruhi kondisi ibu berupa kelelahan, rasa takut, khawatir dan menimbulkan stress (Purwaningrum, 2012:66-67).

Sejak tahun 2015 penekanan persalinan yang aman adalah persalinan yang ditolong oleh tenaga kesehatan difasilitas pelayanan kesehatan. Pada cakupan persalinan di fasilitas kesehatan menunjukkan bahwa terdapat $83,67 \%$ ibu hamil yang menjalani persalinan dengan ditolong oleh tenaga kesehatan dan dilakukan difasilitas pelayanan kesehatan di Indonesia. Sedangkan di Provinsi Jambi terdapat $73,74 \%$ ibu hamil yang menjalani persalinan dengan ditolong oleh tenaga kesehatan dan dilakukan difasilitas pelayanan kesehatan (Profil Kesehatan Indonesia, 2017).

Data persatuan rumah sakit di seluruh Indonesia menjelaskan bahwa $15 \%$ ibu di Indonesia mengalami komplikasi persalinan dan $21 \%$ menyatakan bahwa persalinan yang dialami merupakan persalinan yang menyakitkan, sedangkan $63 \%$ tidak memperoleh informasi tentang persiapan yang harus dilakukan guna mengurangi nyeri pada persalinan (AstriedMulyani, 2017:203).

Hasil penelitian Tounair (2007) dalam buku Karlinah Nelly (2015) menyatakan nyeri persalinan ringan terjadi pada 15 kasus, nyeri sedang $35 \%$, nyeri berat $30 \%$, dan nyeri ekstrim terjadi pada $20 \%$ kasus. Bagi seorang ibu, melahirkan bayi adalah peristiwa yang sangat membahagiakan sekaligus peristiwa yang berat penuh tantangan dan kecemasan.

Menurut Arifin (2008), nyeri persalinan kala I fase aktif diakibatkan oleh kontraksi rahim yang mulai adekuat terjadi 3-5 kali dalam 10 menit dengan lama kontraksi antara 30-60 detik. Gerakan kontraksi rahim menyebabkan otot-otot dinding rahim mengkerut, menjepit pembuluh darah, vagina dan jaringan lunak di sekitarnya merenggang, sehingga terasa nyeri. Keadaan mental ibu (ketakutan, cemas, khawatir atau tegang) serta hormone prostaglandin yang meningkat sebagai respon terhadap stress. Intensitas nyeri selama kala I fase aktif ini diakibatkan oleh kekuatan kontraksi dan tekanan yang dibangkitkan. Semakin besar distensi abdomen, intensitas nyeri menjadi lebih berat. Nyeri dapat menyebabkan peningkatan tekanan darah, denyut nadi, pernafasan, keringat, ketegangan otot dan konsentrasi ibu selama persalinan menjadi terganggu. Jika ibu tidak dapat menahan rasa nyeri, semua itu bisa berefek buruk terhadap kelancaran persalinan sehingga terjadi persalinan lama. Ini akan mengakibatkan distress pada bayi dan mempengaruhi bayi yang akan dilahirkan.

Menurut penelitian Apriliyani Mafikasari dan Ratih Indah Kartikasari (2015), prevalensi ibu hamil yang mengalami nyeri punggung bawah di berbagai daerah Indonesia mencapai 60-80\%. Berdasarkan hasil penelitian Ariyanti (2012), didapatkan bahwa sebesar $68 \%$ ibu hamil mengalami nyeri punggung dengan intensitas sedang dan $32 \%$ ibu hamil mengalami nyeri punggung dengan intensitas ringan. Penelitian Handayani (2011) dengan judul Pengaruh effleurage massage Terhadap Nyeri Primipara Kala I Persalinan 
Fisiologis di RSIA Bunda Arif Purwokerto membuktikan bahwa effleurage massage dapat mengurangi nyeri dari skala 7,647 menjadi 6,117.

Dalam laporan penelitian Steer (1993) 19,3\% wanita dilaporkan mendapat massase untuk meredakan nyeri persalinan (Rosemary 2003 : 163) Malkin merinci 6 gerakan dasar diantaranya adalah effleurage massage. Teknik pijat effleurage banyak diterapkan di Negara barat seperti Perancis. Teknik pijat effleurage dapat menimbulkan efek distraksi dan relaksasi, sehingga membantu ibu menjadi lebih rileks, menciptakan perasan nyaman, enak dan respon nyeri akan menurun. Di Indonesia teknik ini masih belum popular dan masih jarang dilakukan (Danuatmaja, 2004:67).

Tindakan utama effleurage massage merupakan aplikasi dari teori Gate Control yang dapat "menutup gerbang" untuk menghambat perjalanan rangsang nyeri pada pusat yang lebih tinggi pada system saraf pusat. Berdasarkan penelitian Wahyuni (2015), menunjukan bahwa effleurage massage dapat menurunkan nyeri.

Berdasarkan survey awal di PMB Nuri pada bulan Januari diperoleh data ibu bersalin selama bulan Januari-Desember 2018 sebanyak 295 orang jadi rataratanya 25 orang tiap bulan, sedangkan data ibu bersalin di PMB Latifah pada bulan Januari-Desember 2018 sebanyak 82 orang, jadi rata-ratanya 6 orang tiap bulan.

Terdapat 2 dari 3 pasien sedang dalam persalinan kala I pada ibu primi gravida menyatakan tidak tahan dengan nyeri yang dirasakan terutama pada kala I. Ibu merasakan nyeri dibagian perut, pinggang, punggung dan menjalar ketulang belakang. Di Praktik Mandiri Bidan Nuriman Rafida dan Praktik Bidan Mandiri Latifah tersebut belum memberikan terapi nonfarmakologi seperti effleurage massage kepada ibu, sehingga ibu terus merasakan nyeri saat melahirkan.

Berdasarkan latar belakang diatas penulis akan melakukan penelitian mengenai Pengaruh Effleurage Massage Terhadap Nyeri pada Kala I FaseAktif di Praktik Mandiri Bidan Nuriman Rafida dan Praktik Bidan Mandiri Latifah Kota Jambi.

\section{Tinjauan Pustaka \\ Persalinan}

\section{Pengertian Persalinan}

Menurut Varney (2007), Persalinan adalah serangkaian proses yang berakhir dengan pengeluaran hasil konsepsi oleh ibu. Proses ini dimulai dari kontraksi persalinanyang ditandai oleh perubahan progresif pada servik dan diakhiri dengan pengeluaran plasenta.

Persalinan normal menurut WHO adalah persalinan dengan presentasi janin belakang kepala yang berlangsung secara spontan dengan lama persalinan dalam batas normal, berisiko rendah sejak awal persalinan hingga partus dengan masa gestasi 37 sampai 42 minggu.

Persalinan normal menurut IBI adalah persalinan dengan presentasi janin belakang kepala yang berlangsung secara spontan dengan lama persalinan dalam batas normal, tanpa intervensi (penggunaan narkotik, epidural, oksitosin, percepatan persalinan, memecahkan ketuban dan episiotomy), berisiko rendah sejak awal persalinan hingga partus dengan masa gestasi 37 sampai 42 minggu.

\section{Kala I Persalinan}

Menurut Prawirohardjo (2010), kala I persalinan dimulaiketika telah tercapainya kontraksi uterus dengan frekuensi, intensitas dan durasi yang cukup untuk menghasilkan pendataran dan dilatasi serviks yang progresif. Kala I persalinan selesai ketika serviks sudah membuka lengkap (sekitar $10 \mathrm{~cm}$ ) sehingga memungkinkan kepala janin lewat, oleh karena itu kala I persalinan disebut stadium pendataran dan dilatasi serviks.

Berdasarkan kemajuan pembukaan serviks kala I dapat dibagi menjadi:

a. Fase laten, yaitu fase pembukaan yang sangat lambat dari 0 sampai $3 \mathrm{~cm}$ yang membutuhkan waktu \pm 8 jam.

b. Fase aktif, yaitu fase pembukaan yang lebih cepat yang terbagi lagi menjadi:

1) Fase akselerasi (fase percepatan)

Dari pembukaan $3 \mathrm{~cm}$ sampai $4 \mathrm{~cm}$ umumnya berlangsung selama 2 jam. Fase ini merupakan fase persiapan menuju fase berikutnya.

2) Fase dilatasi maksimal

Fase ini merupakan waktu ketika dilatasi serviks meningkat dengan cepat. Dari pembukaan $4 \mathrm{~cm}$ menjadi $9 \mathrm{~cm}$ selama 2 jam. Normalnya pembukaan serviks pada fase ini konstan yaitu 2$3 \mathrm{~cm}$ perjam untuk multipara dan $1-2 \mathrm{~cm}$ per jam untuk primipara.

3) Fase deselerasi

Fase ini merupakan akhir fase aktif dimana dilatasi serviks dari $9 \mathrm{~cm}$ menuju pembukaan lengkap $(10 \mathrm{~cm})$. dilatasi serviks pada fase ini kembali menjadi lambat rata-rata $1 \mathrm{~cm}$ per jam pada primipara namun pada multipara lebih cepat.

\section{Asuhan Persalinan Kala I}

Menurut Indrayani (2016), asuhan persalinan kala I merupakan asuhan yang dibutuhkan ibu saat proses persalinan. asuhan ini bertujuan untuk mengupayakan kelangsungan hidup dan mencapai derajat kesehatan yang tinggi bagi ibu dan bayinya, melalui berbagai upaya yang terintegrasi dan lengkap serta intervensi minimal sehingga prinsip keamanan dan kualitas pelayanan dapat terjaga pada tingkat yang optimal.

Asuhan sayang ibu asuhan yang saling menghargai budaya, kepercayaan dari keinginan ibu pada asuhan yang aman selama proses persalinan serta melibatkan ibu dan keluarga sebagai pembuat keputusan, tidak emosional dan sifatnya mendukung.

Dukungan dari pemberi asuhan dalam persalinan harus bersifat fisik dan emosional. Asuhan sayang ibu pada persalinan kala I, meliputi:

a. Memberikan dukungan emosional berupa pujian dan semangat agar ibu mampu melewati proses persalinan dengan baik.

b. Memberikan pemijatan pada punggung ibu untuk meringankan rasa sakit pada punggung ibu dan mengusap keringat ibu.

c. Menganjurkan ibu untuk mandi dan gosok gigi terlebih dahulu jika ibu masih kuat untuk berjalan. 
d. Menciptakan suasana kekeluargaan dan rasa aman

e. Menganjurkan ibu untuk berjalan pada saat kala I dan mengatur posisi yang nyaman bagi ibu kecuali posisi terlentang dengan melibatkan keluarga

f. Menganjurkan ibu untuk makan makanan ringan dan minum jika ibu mau

g. Menghadirkan pendamping persalinan yang sesuai dengan keinginan ibu

h. Membimbing ibu cara meneran yang baik bila ada dorongan meneran

i. Menganjurkan ibu untuk buang air kecil jika ibu mau

j. Menjaga privasi ibu

\section{Nyeri Persalinan}

Nyeri adalah suatu keadaan yang tidak menyenangkan dan kompleks yang merupakan fenomena yang sangat individual dengan komponen sensorik dan emosional. Ibu hamil biasanya khawatir terhadap nyeri yang akan mereka hadapi saat persalinan dan kelahiran serta bagaimana mereka akan bereaksi terhadap nyeri dan untuk mengatasi rasa sakit tersebut. Ada berbagai metode non farmakologis dan farmakologis dapat digunakan untuk membantu ibu mengatasi nyeri persalinan. Metode yang dipilih tergantung pada situasi, ketersediaan dan pilihan ibu dan penolong persalinannya.

Rasa nyeri pada persalinan terjadi pada awal persalinan sampai pembukaan lengkap akan berlangsung 12-18 jam, dilanjutkan kala pengeluaran janin sampai pengeluaran plasenta. Rasa nyeri ini dipengaruhi oleh kelelahan, keletihan, kecemasan dan rasa takut yang akan menyebabkan peningkatan rasa nyeri.

Rasa nyeri selama proses persalinan mengakibatkan pengeluaran adrenalin. Pengeluaran adrenalin ini akan mengakibatkan pembuluh darah berkontraksi sehingga akan mengurangi aliran darah yang membawa oksigen ke uterus dan mengakibatkan penurunan kontraksi uterus yang akan menyebabkan memanjangnya waktu persalinan, sehingga menghilangkan rasa takut dan nyeri selama proses persalinan menjadi hal yang cukup penting.

Nyeri dirasakan ibu pada kala I atau saat kontraksi berlangsung. Pada kondisi ini terjadi nyeri visceral dan terasa seperti rasa mules yang berasal dari uterus dan serviks. Rasa nyeri disebabkan oleh meregangnya uterus dan dilatasi serviks.

Nyeri dapat dirasakan pada dinding abdomen, daerah lumbosakralis, krista iliaka, bokong dan paha. Pada kala I aktif sensasi nyeri dirasakan amat sangat kuat. Sensasinya membuat ekspresi ibu terlihat tidak berdaya, kemampuan pendengaran, dan konsentrasi ibu juga menurun (Indrayani dkk, 2016:93-95).

\section{Skala Nyeri}

a. Skala deskripsi intensitas nyeri sederhana

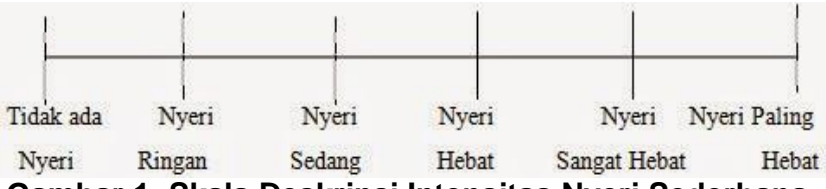

Gambar 1. Skala Deskripsi Intensitas Nyeri Sederhana (Mohamad, 2012) b. Skala intensitas nyeri numerik

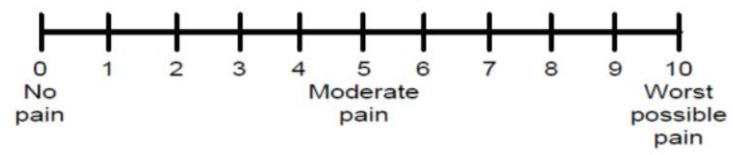

Gambar 2. Skala numerik (Mohamad, dkk, 2012)

Cara untuk mengukur tingkat nyeri adalah dengan menggunakan skala NRS (Numerical rating scale) berdasarkan penilaian objektif yaitu:

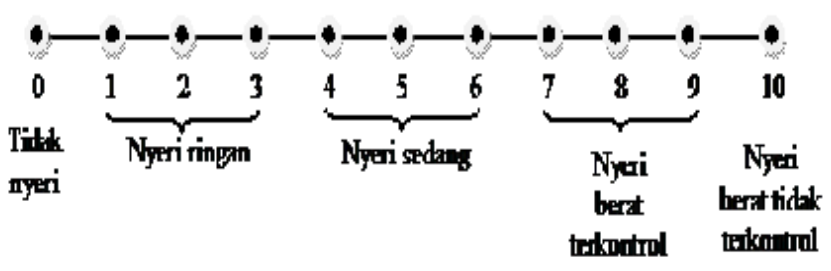

Keterangan:

Semakin besar nilai,maka semakin berat intensitas nyerinya.

1) Skala $0=$ Tidak nyeri

2) Skala 1-3 =nyeri ringan

Secara objektif klien dapat berkomunilasi dengan baik, tindakan manual di rasakan sangat membantu.

3) Skala 4-6 = nyeri sedang

Secara objektif klien mendesis, menyerengai, dapat menunjukan lokasi nyeri dengan tepat dan dapat mendeskripsikan nyeri, klien dapat mengikuti perintah dengan baik dan responsive terhadap tindakan manual.

4) Skala 7-9 =nyeri berat

Secara objekttif terkadang klien dapat mengikuti perintah tapi masih responsive terhadap tindakan manual, dapat menunjukan lokasi nyeri tapi tidak dapat mendeskripsikannya, tidak dapat diatasi dengan alih posisi, nafas Panjang dan destruksi dll.

5) Skala 10 =nyeri sangat berat (panik tidak terkontrol) Secara objektif klien tidak mau berkomunikasi dengan baik berteriak dan histeris, klien tidak dapat mengikuti perintah lagi, selalu mengejan tanpa dapat dikendalikan, menarik-narik apa saja yang tergapai, dan tidak dapat menunjukan lokasi nyeri (Mohamad, 2012:36).

\section{Faktor- Faktor yang Memengaruhi Nyeri Persalinan}

1. Faktor Internal

a. Pengalaman dan pengetahuan tentang nyeri

Pengalaman sebelumnya seperti persalinan terdahulu akan membantu ibu dalam mengatasi nyeri, karena ibu telah memiliki koping terhadap nyeri. Ibu multipara dan primipara kemungkinan akan berespon terhadap nyeri berbeda-beda walaupun menghadapi kondisi yang sama yaitu suatu persalinan. Hal ini dikarenakan ibu multipara telah memiliki pengalaman pada persalinan sebelumnya.

b. Usia

Usia muda cenderung dikaitkan dengan kondoso psikologis yang masih labil, yang memicu terjadinya kecemasan sehingga nyeri yang dirasakan menjadi lebih berat. Usia juga dipakai sebagai salah 
satu factor dalam menentukan toleransi terhadap nyeri. Toleransi akan meningkat seiring bertambahnya usia dan pehaman terhadap nyeri.

c. Aktifitas fisik

Aktifitas ringan bermanfaat mengalihkan perhatian dan mengurangi rasa sakit menjelang persalinan, selama itu tidak melakukan latihan-latihan yang tidak terlalu keras dan berat, serta menimbulkan keletihan pada wanita karena hal ini justru akan memicu nyeri yang lebih berat.

d. Kondisi psikologi

Situasi dan kondisi psikologis yang labil memegang peranan penting dalam memunculkan nyeri persalinan yang lebih berat. Salah satu mekanisme pertahanan jiwa terhadap stress adalah konversi yaitu memunculkan gangguan secara psikis menjadi gangguan fisik.

\section{Faktor Eksternal}

a. Agama

Semakin kuat kualitas keimanan seseorang maka mekanisme pertahanan tumbuh terhadap nyeri semakin baik karena berkaitan dengan kondisi psikologis yang relative stabil.

b. Lingkungan fisik

Lingkungan yang terlalu ekstrim seperti perubahan cuaca, panas, dingin, ramai, bising memberikan stimulus terhadap tubuh yang memicu terjadinya nyeri.

c. Budaya

Budaya tentu akan mempengaruhi respon seseorang terhadap nyeri, ada budaya yang mengekspresikan nyeri secara bebas, tapi ada pula yang tidak perlu di ekspresikan secara berlebihan.

d. Support system

Tersedianya sarana dan support system yang baik dari lingkungan dalam mengatasi nyeri, dukungan keluarga dan orang terdekat sangat membantu mengurangi rangsangan nyeri yang dialami oleh seseorang saat menghadapi persalinan.

e. Social ekonomi

Tersedianya sarana dan lingkungan yang baik dapat membantu mengatasi rangsang nyeri yang dialami. Seringkali status ekonomi mengikuti keadaan nyeri persalinan. Keadaan ekonomi yang kurang, pendidikan yang rendah, informasi yang minimal dan kurang sarana kesehatan yang memadai akan menimbulkan ibu kurang mengetahui bagaimana mengatasi nyeri yang dialami dan masalah ekonomi berkaitan dengan biaya dan persiapan persalinan sering menimbulkan kecemasan tersendiri dalam menghadapi persalinan.

\section{Lama Nyeri Persalinan}

Nyeri selama persalinan dirasakan selama kala pembukaan dan makin hebat dalam kala pengeluaran. Pada ibu yang baru pertama kali bersalin, kala pembukaan berlangsung kira-kira 13 jam dan kala pengeluaran kira-kira $1^{1 / 2}$ jam. Pada wanita yang pernah melahirkan kala pembukaan berlangsung lebih singkat yaitu sekitar 7 jam dan kala pengeluaran sekitar $1 / 2$ jam (Maya,2010).

\section{Akibat Tidak Mengatasi Nyeri}

Menurut Mander (2004), nyeri persalinan yang berat dan lama dapat mempengaruhi ventilasi, sirkulasi metabolisme dan aktivitas uterus. Nyeri saat persalinan bisa menyebabkan tekanan darah meningkat dan konsentrasi ibu selama persalinan menjadi terganggu, tidak jarang kehamilan membawa "stress" atau rasa khawatir/cemas yang membawa dampak dan pengaruh terhadap fisik dan psikis, baik pada ibu maupun pada janin yang dikandungnya. Misalnya mengakibatkan kecacatan jasmani dan kemunduran kepandaian serta mental emosional nyeri dan rasa sakit yang berlebihan akan menimbulkan rasa cemas. Rasa cemas yang berlebihan juga menambah nyeri.

\section{Penyebab Nyeri saat Persalinan}

Kontraksi uterus pada setiap orang sangatlah unik, mengikuti kontraksi otot-otot di uterus. Dalam perkembangan proses persalinan kontraksi akan bertambah panjang dan kuat, kekurangan oksigen pada sel-sel akan semakin meningkat. Hal ini yang menyebabkan intensitas nyeri juga akan semakin meningkat.

Nyeri pada proses persalinan ini juga bisa disebabkan oleh tarikan dan tekanan yang terjadi pada jalan lahir. Pada akhir dari proses persalinan saat terjadi pembukaan jalan lahir lengkap, ibu akan merasakan ingin mengejan karena dengan mengejan rasa nyeri yang dialami akan hilang. Bertambahnya ketidaknyamanan atau nyeri pada proses persalinan juga karena penekanan bagian presentasi janin di organ-organ yang berada di sekitar jalan lahir seperti: kandung kencing, uretra (saluran kencing), dan kolon. Nyeri yang terbesar dirasakan ibu saat kelahiran adalah nyeri akibat tarikan pada jaringan perineum. Perineum adalah bagian pelindung dan otot yang memanjang dari depan vagina atau jalan lahir menuju ke anus. (Wenny Artanty Nisman,2011:44)

Kecemasan menurun jika seseorang mengetahui saat kontraksi akan terjadi dan lamanya perasaan tersebut akan berakhir. Kurang pengetahuan akibat tidak mengikuti kelas persiapan melahirkan merupakan salah satu faktor predisposisi takut saat hamil atau kecemasan ketika persalinan. pemberian pengetahuan dan informasi dapat mengurangi masalahkesehatan, tetapi latihan relaksasi dan metode penanggulangan nyeri diperlukan untuk mengurangi kecemasan. (Indrayani dkk, 2016:116)

\section{Metode Penanggulangan Nyeri}

Penanggulangan nyeri pada persalinan terdapat 2 cara yaitu farmakologi dan non-farmakologi. Tindakan non-farmakologi selalu lebih sederhana dan aman, kalaupun ada hanya memiliki sedikit efek samping utama, relatif murah dan dapat digunakan diseluruh persalinan.

\section{Cara Farmakologi}

Menurut Wenny (2011), penggunaan obat-obatan pada periode persalinan dan kelahiran harus mempertimbangkan keselamatan 2 orang yaitu ibu dan janin yang dikandung. Kadang-kadang ibu terlalu takut menghadapi persalinan terutama karena nyeri yang akan dirasakan. Lalu mereka meminta pemberian obat- 
obatan tanpa mempertimbangkan pemberian obatobatan tersebut dapat mempengaruhi kondisi janin. Obat-obatan yang diberikan bermacam-macam, yang biasanya diberikan dengan cara disuntikkan oleh seorang dokter ahli anastesi.

Pemberian obat-obatan ini, ibu dan bayi juga dalam pengawasan dokter sehingga jika terdapat pengaruh yang tidak diinginkan segera dapat diatasi. Sebagian besar obat-obatan yang diberikan pada saat persalinan dan kelahiran bayi berfungsi sebagai analgetik atau mengurangi rasa sakit. Selain itu, juga ada obat yang berperan untuk mengurangi kecemasan, mual muntah, dan ketidaknyamanan pada proses persalinan. Akan tetapi yang perlu diingat, masingmasing obat mempunyai efek samping yang perlu diperhatikan dan harus diberikan sepengawasan dokter ahli dibidangnya.

\section{Cara Non-Farmakologis}

Tindakan non-farmakologis selalu lebih sederhana dan aman, kalaupun ada hanya memiliki sedikit efek samping utama, relative murah dan dapat digunakan diseluruh persalinan. Banyak metode non-farmakologis untuk menghilangkan ketidaknyamanan yang diajarkan dalam berbagai jenis kelas persiapan kehamilan. Seringkali metode non-farmakologis digunakan dan dikombinasikan dengan metode farmakologis terutama karena kemajuan persalinan.

\section{a. Relaksasi}

Relaksasi atau peregangan tubuh adalah teknik yang disarankan oleh hampir semua kelas persiapan persalinan.Bukti menunjukkan bahwa relaksasi dapat meningkatkan pengelolaan nyeri persalinan. Relaksasi idealnya dikombinasikan dengan aktivitas seperti berjalan, menari lambat, goyang dan perubahan posisi yang membantu bayi memutar melalui panggul. Gerak ritmis merangsang mechanoreceptors diotak, yang dapat menurunkan persepsi nyeri.

b. Imageri dan Visualisasi

Membayangkan sesuatu atau guided imagery memiliki prinsip yang hampir sama dengan distraksi. Intinya adalah agar tidak berfokus pada nyeri yang dialami. Selain untuk mengatasi nyeri, teknik ini juga tepat digunakan untuk mengatasi stress, ketegangan dan kecemasan. Sebaiknya Teknik guided imagery ini dilakukan pada ruangan khusus tersendiri dengan tambahan fasilitas yang lain seperti musik lembut dan aroma terapi untuk memperkuat efek relaksasi. Ibu berbaring dengan posisi rileks, diruangan yang tenang dan sejuk juga sangat membantu keberhasilan teknik ini.

c. Massage

Pijat atau massage adalah kontak fisik sumber rasa nyaman dan penghibur hati kapan saja, tetapi lebih khususnya selama kehamilan. Pemijatan bisa menjadi sarana yang membuat ibu rileks, mendekatkan ibu dengan suami dan juga berguna pada tahap pertama persalinan untuk menghilangkan sakit punggung dan menentramkan, menenangkan dan menyejukkan si ibu.

Menurut Henderson \& Jones, definisi massage adalah tindakan penekanan oleh tangan pada jaringan lunak, biasanya otot tendon atau ligament tanpa menyebabkan pergeseran atau perubahan posisi sendi guna menurunkan nyeri, menghasilkan relaksasi dan atau meningkatkan sirkulasi.Sebuah penelitian menyebutkan ibu yang dipijat selama 20 menit setiap jam selama tahapan persalinan akan lebih bebas dari rasa sakit, karena pijat merangsang tubuh melepaskan senyawa endorphin yang merupakan pereda sakit alami dan menciptakan perasaan nyaman dan enak. Bagian tubuh ibu yang dapat dipijat adalah kepala, bahu, perut, kaki dan tangan, punggung serta tungkai. Saat memijat, pemijat harus memperhatikan respon ibu apakah tekanan yang diberikan sudah tepat.

Illustrasi Gate Control Teory bahwa serabut nyeri membawa stimulasi nyeri ke otak lebih kecil dan perjalanan sensasinya lebih lambat dari pada serabut sentuhan yang luas. Ketika sentuhan dan nyeri dirangsang bersama, sensasi sentuhan berjalan ke otak menutup pintu gerbang dalam otak. Dengan adanya pijatan atau sentuhan yang mempunyai efek distraksi juga dapat meningkatkan pembentukan endorphin dalam system control desenden dan membuat relaksasi otot.

Bagan 1. Hubungan Antara Massage Dan Nyeri Berdasarkan Teori Gate Control (Mander, 2012:164)

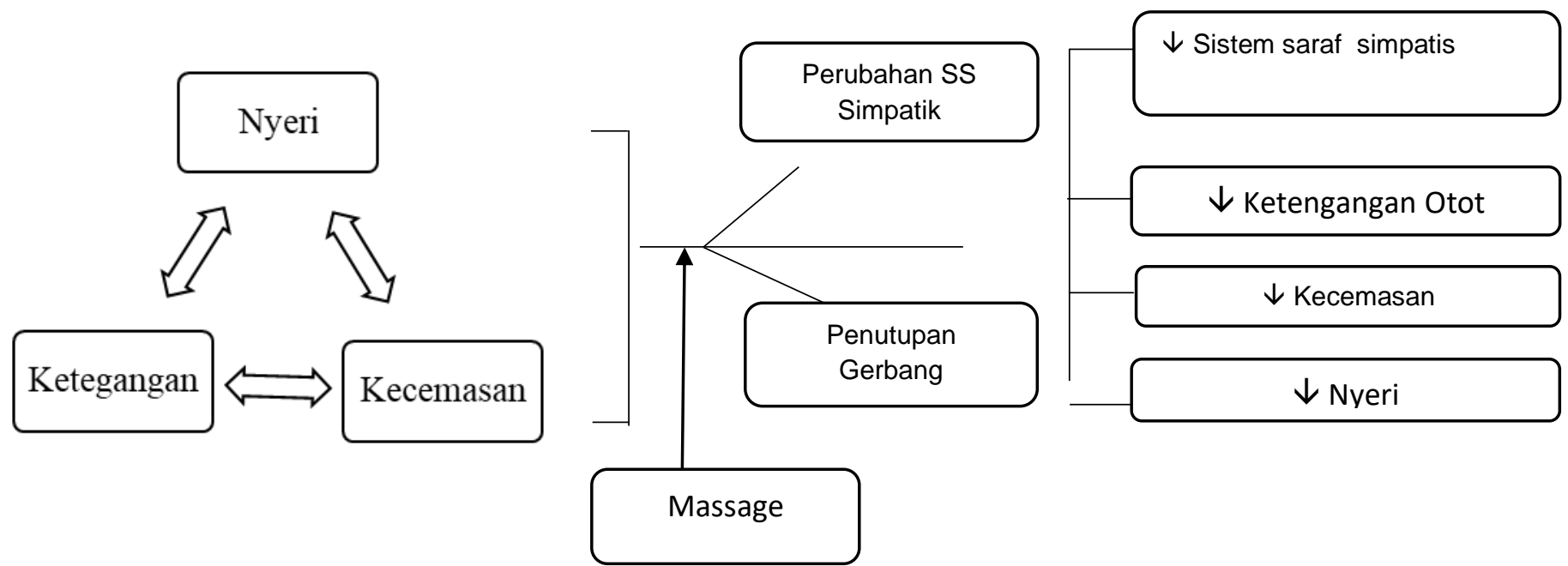




\section{d. Teknik pernapasan}

Teknik pernapasan perlu diajarkan pada kelas persiapan persalinan untuk mempersiapkan ibu agar dapat menghadapi stress saat melahirkan. Teknik ini diharapkan dapat membuat ibulebih rileks sehingga mengurangi persepsi nyeri dan membantu ibu mempertahankan dirinya terhadap nyeri selama kontraksi.

Ibu dapat mengendalikan keinginan untuk meneran dengan cara mengambil nafas terengahengah atau dengan perlahan menghembuskan nafas melalui bibir mengerucut seolah-olah meniup lilin atau meledakkan balon. Jenis pernafasan ini dapat digunakan untuk mengatasi keinginan untuk meneran ketika serviks belum sepenuhnya siap dan untuk memfasilitasi kelahiran kepala janin secara lambat atau mencegah defleksi kepala yang terlalu cepat.

e. Sentuhan dan pijat

Terapi sentuhan digunakan untuk kenyamanan dan mengurangi nyeri. Dasar dari konsep ini adalah sentuhan mengandung medan energi yang menyehatkan. Jadi, semakin ibu mendapatkan banyak suplai energi maka semakin sehat. Akan tetapi, jika kekurangan suplai energi akan menghasilkan sakit. Berdasarkan penelitian lanjutannya ternyata dengan sentuhan dan pijatan dapat menghasilkan endorphin alami tubuh yang dapat mengurangi nyeri pada bagian tubuh yang terasa nyeri.

f. Aplikasi panas dan dingin

Pada saat persalinan ternyata aplikasi panas atau dingin ini juga efektif untuk menurunkan rasa tidak nyaman yang dialami ibu. Salah satu contoh saat proses persalinan, ibu mengalami nyeri pada daerah punggung bawah, maka dapat dilakukan kompres hangat untuk membantu kenyamanan ibu. Duduk atau berbaring di bathtub air hangat juga dapat dilakukan selama tahap satu persalinan selama selaput ketuban masih utuh. Tujuannya adalah untuk meningkatkan kenyamanan ibu. Kondisi ruang persalinan yang kurang mendukung sering membuat ibu merasa kepanasan. Saat seperti ini tepat digunakan air dingin untuk membasuh muka ibu untuk mengembalikan kesegaran dan meningkatkan kenyamanan ibu.

g. Akupresur dan akupuntur

Teknik akupunture mempunyai konsep dasar bahwa penyakit terjadi karena ketidakseimbangan energi. Untuk mengkoreksi ketidakseimbangan energi dilakukan dengan memasukkan jarum ke kulit. Lokasi pemasukan jarum ditujukan pada organ bagian tubuh yang akan disuplai energinya tetapi tidak perlu berdekatan dengan organ yang dipengaruhinya. Aktivasi dari titik yang dilakukan penusukan ini akan mengeluarkan endorphin.

h. Bathing atau Hidroterapi

Berdiri dibawah shower dengan air hangat atau berendam di bathtub dengan air hangat dapat digunakan pada terapi air. Sensasi hangat dapat mengurangi rasa nyeri. Temperature yang dianjurkan adalah $36,6-37,8^{\circ} \mathrm{C}$. Syarat yang harus dipenuhi adalah selaput ketuban masih utuh atau air ketuban belum keluar. Apabila selaput ketuban telah pecah akan meningkatkan risiko ibu dan bayi mengalami infeksi.

i. Hipnobirthing

Hypnobirthing adalah suatu teknik hypnosis yang digunakan untuk memberikan kenyamanan, ketenangan dan kenikmatan saat menjalani persalinan. Dalam teknik ini memerlukan beberapa fase untuk mencapainya antara lain: relaksasi yang mendalam, pola pernapasan lambat, pemberian petunjuk cara melepaskan endorphin dari dalam tubuhyang memungkinkan calon ibu menikmati proses kelahiran yang aman, lembut dan cepat. Teknik hypnosis awalnya dilakukan oleh seorang hipnoterapi tetapi kemudian jika ibu sudah dapat melakukannya sendiri maka dilakukan auto-hipnosis. Hypnosis bukanlah magic tetapi merupakan teknik pemberdayaan alam bawah sadar dengan mengistirahatkan alam sadar manusia. Manfaat penggunaan teknik hypnosis pada periode persalinan adalah membantu menyeimbangkan morphin alami dalam tubuh untuk mengurangi rasa nyeri, membuat semua bagian tubuh yang berperan pada proses persalinan dapat bekerja dengan baik, serta membantu menyehatkan $70 \%$ air pada tubuh orang dewasa dan $9 \%$ air pada tubuh bayi yang terkandung dalam tubuh agar menjadi air yang heksagonal. Menurut Masaru Emoto (2001), air yang heksagonal dapat lebih menyehatkan organ tubuh manusia.

\section{Effleurage Massage}

Menurut Indrayani (2016) terdapat 2 teknik massage yang dapat mengurangi nyeri yaitu Effleurage (pijatan ringan) dan counterpressure (penekanan) telah banyak membantu perempuan selama kala I persalinan.

\section{Definisi Effleurage Massage}

Effleurage merupakan salah satu metode non farmakologis untuk mengurangi nyeri selama persalinan yang terdaftar dalam Summary of pain relief measures during labor, dimana pada kala I fase laten (pembukaan 0-3 cm) dan fase aktif (pembukaan 4-7 cm) aktivitas yang bisa dilakukan oleh ibu persalinan adalah effleurage.

Effleurage adalah pijatan ringan dengan menggunakan jari tangan, biasanya pada perut, seirama dengan pernapasan saat kontraksi. Effleurage dapat dilakukan oleh ibu bersalin sendiri atau pendamping persalinan selama kontraksi berlangsung. Hal ini digunakan untuk mengalihkan perhatian ibu dari nyeri saat kontraksi.

\section{Teknik Effleurage Massage}

Beberapa pola teknik effleurage tersedia, pemilihan pola pemijatan tergantung pada keinginan masing-masing pemakai dan manfaatnya dalam memberikan kenyamanan. Pola teknik effleurage yang bisa dilakukan untuk mengurangi nyeri persalinan akibat kontraksi uterus adalah:

\section{a. Teknik menggunakan dua tangan}

Teknik ini bisa dilakukan oleh ibu inpartu sendiri dengan menggunakan kedua telapak jari-jari 
tangan melakukan usapan ringan, tegas dan konstan dengan cara gerakan melingkari abdomen, dimulai dari abdomen bagian bawah diatas simpisis pubis, mengarah ke samping perut, terus ke fundus uteri kemudian turun ke umbilicus dan kembali ke perut bagian bawah di samping simpisis pubis (Bobak,2005:57)

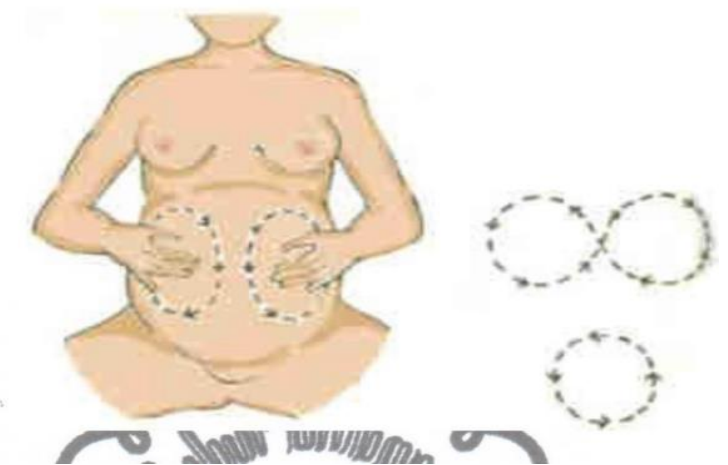

Gambar 3. Teknik pijat Effleurage dengan dua tangan oleh ibu inpartu

b. Teknik menggunakan satu tangan

Teknik ini dapat dilakukan oleh orang lain (suami, keluarga atau petugas kesehatan) dengan menggunakan ujung-ujung jari tangan melakukan usapan pada abdomen secara ringan, tegas, konstan dan lambat dengan membentuk pola gerakan seperti angka delapan (Bobak,2005:58)

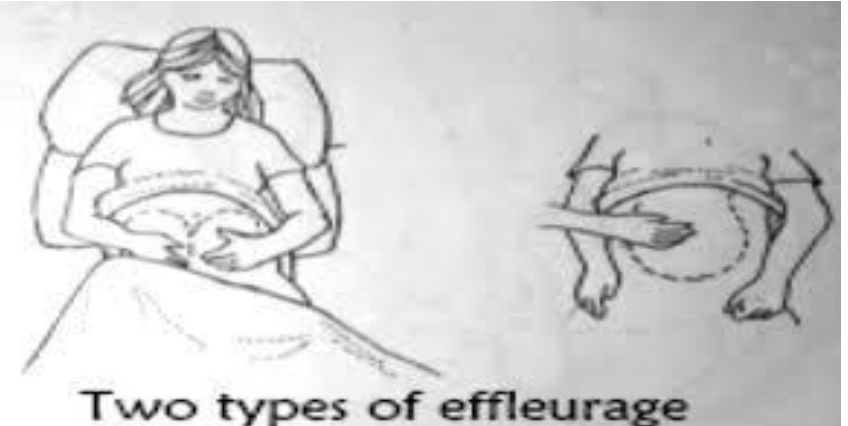

Gambar 4. Teknik pijat Effleurage dengan satu tangan

c. Teknik pemijatan lain yang dapat dilakukan pasangan atau pendamping persalinan selama persalinan adalah: a) Melakukan usapan dengan menggunakan seluruh telapak tangan pada lengan atau kaki dengan lembut

b) Melakukan masase pada wajah dan dagu dengan lambat

c) Selama kontraksi berlangsung, lakukan usapan ringan pada bahu dan punggung

d) Melakukan gerakan membentuk pola 2 lingkaran dipaha ibu bila tidak dapat dilakukan diabdomen Fasilitasi jika ibu ingin menyewa seorang terapis pijat professional untuk mendampinginya selama persalinan. Pengetahuan dan keahlian terapis pijat professional akan mampu menggabungkan teknik lain seperti refleksologi dan penggunaan titik-titik tekanan.

\section{Cara Melakukan Effleurage Massage}

Prosedur tindakan stimulasi kulit dengan teknik effleurage massageyaitu:

a. Atur posisi tidur ibu dengan posisi tidur telentang rileks dengan menggunakan 1 atau 2 bantal, kaki diregangkan $10 \mathrm{~cm}$ dengan kedua lutut fleksi dengan membentuk sudut $45^{\circ}$

b. Pada waktu timbulnya kontraksi, kaji respon fisiologis dan psikososial ibu lalu tanyakan kualitas nyeri yang dirasakan berdasarkan skala nyeri.

c. Pada waktu timbul kontraksi berikutnya, letakkan kedua telapak ujung-ujung jari tangan diatas simpisis pubis bersama inspirasi pelan, usapkan kedua ujungujung jari tangan dengan tekanan yang ringan, tegas dan konstan ke samping abdomen, mengelilingi samping abdomen menuju kearah fundus uteri, setelah sampai fundus uteri seiring dengan ekspirasi pelan-pelan usapkan kedua ujung-ujung jari tangan tersebut menuju perut bagian bawah di atas simpisis pubis melalui umbilicus.Lakukan gerakan ini berulang-ulang selama ada kontraksi.

d. Sesudah dilakukan perlakuan, kaji respon fisiologis dan psikologis ibu dan tanyakan kualitas nyeri yang dirasakan berdasarkan skala nyeri

Berdasarkan teori Indrayani (2016:136) Penatalaksanaan nyeri persalinan dapat dilakukan dengan effleurage massage untuk mengalihkan perhatian ibu dari nyeri saat kontraksi. Untuk lebih jelasnya dapat dilihat di Bagan 2 Input

Bagan 2. Penatalaksanaan Nyeri Persalinan Kala I Dengan Effleurage Massage

\begin{tabular}{|c|c|c|}
\hline Input & Proses & Output \\
\hline $\begin{array}{c}\text { Persalinan kala I fase } \\
\text { aktif dengan } \\
\text { intensitas nyeri }\end{array}$ & $\begin{array}{l}\text { Penatalaksanaan } \\
\text { effleurage massage }\end{array}$ & $\begin{array}{c}\text { Perubahan } \\
\text { intensitas nyeri }\end{array}$ \\
\hline
\end{tabular}

\section{METODE PENELITIAN \\ Desain Penelitian}

Penelitian ini adalah penelitian quasi experimental design dengan rancangan yang digunakan adalah pretest-posttest one group design bertujuan untuk mengetahui pengaruh perlakuan tersebut terhadap intensitas nyeri persalinan kala I fase aktif.

\section{Lokasi dan Waktu Penelitian}

Penelitian ini dilakukan di Praktik Mandiri Bidan Nuriman Rafida dan Praktik Mandiri Bidan Latifah Kota Jambi Tahun 2019. Penelitian dilakukan mulai dari bulan Desember 2018 sampai Juni 2019. 


\section{Populasi dan Sampel \\ Populasi Penelitian}

Populasi adalah keseluruhan unit dalam pengamatan yang dilakukan (Notoatmojo, 2010:115). Populasi dalam penelitian ini adalah semua ibu bersalin kala I fase aktif di Praktik Mandiri Bidan Nuriman Rafida dan Praktik Bidan Mandiri Latifah sebanyak 30 orang.

\section{Sampel}

Sampel adalah keseluruhan objek penelitian atau objek yang diteliti. Pengambilan sampel dalam penelitian ini dengan menggunakan Total Sampling yaitu teknik pengambilan sampel dengan mengambil semua responden yang ditemui selama penelitian yang termasuk dalam anggota populasi. Sampel dalam penelitian ini adalah ibu bersalin kala I fase aktif sebanyak 30 orang.

Kriteria inklusi adalah criteria atau ciri-ciri yang perlu dipenuhi oleh setiap anggota populasi yang dapat diambil sebagai sampel sedangkan criteria eksklusi adalah criteria populasi yang tidak diambil sebagai sampel.

a. Kriteria inklusi

Merupakan criteria subjek penelitian dapat mewakili sampel penelitian yang memenuhi syarat menjadi sampel (sibagariang dkk, 2010).
1) Bersedia menjadi responden
2) Persalinan fisiologis
3) Ketuban belum pecah
4) Tidak gawat janin

b. Kriteria eksklusi

Merupakan criteria subjek penelitian tidak dapat mewakili sampel karena tidak memenuhi syarat sebagai sampel penelitian (Sibagariang dkk, 2010). Yang menjadi criteria adalah:

1) Ibu dengan pengaruh analgesic atau induksi

2) Ibu dengan gangguan pada kulit local, seperti luka bakar, dermatitis, atau luka.

3) Ibu dengan janin letak lintang

\section{Pengumpulan Data}

\section{Instrument pengumpulan data}

Instrument yang digunakan untuk pengumpulan data adalah lembar observasi yang berisi skala nyeri sebelum dilakukan perlakuan dan sesudah perlakuan. Sebelum dilakukan penelitian responden diberikan penjelasan perihal penelitian yang akan dilakukan.

\section{Pelaksanaan pengumpulan data}

a. Jenis data

Jenis data yang digunakan dalam penelitian ini adalah data primer yaitu data yang didapatkan langsung dari responden melalui observasi tentang rasa nyeri yang dirasakan oleh responden sebelum di lakukan effleurage massage dengan setelah dilakukan effleurage massage pada persalinan normal kala I fase aktif.

b. Metode pengumpulan data

Data yang dikumpulkan dalam penelitian ini adalah respon nyeri yang dirasakan oleh ibu inpartu kala I fase aktif sebelum dilakukan effleurage massage dengan setelah dilakukan effleurage massage. Pengumpulan data dan pemberian effleurage massage dilakukan sendiri oleh peneliti terhadap responden. Responden yang masuk dalam fase aktif (pembukaan serviks 4-10 cm) diobservasi terlebih dahulu selama \pm 30 menit pada tiap-tiap kontraksi tanpa dilakukan intervensi apapun. Setiap respon nyeri ibu yang tampak selanjutnya diberi tanda checklist sesuai dengan kriteria yang tercantum didalam lembar observasi. Setelah pengamatan yang pertama selanjutnya responden diberikan effleurage massage selama \pm 20 menit pada tiap-tiap kontraksi. Setelah dilakukan effleurage massage respon nyeri responden diamati kembali dengan teknik yang sama seperti sebelum dilakukan masase.

\section{Pengolahan Data}

Data yang sudah dikumpulkan selanjutnya diolah melalui tahapan-tahapan berikut ini:

\section{Editing}

Editing digunakan untuk memeriksa daftar pertanyaan yang telah diserahkan oleh para pengumpul data.

\section{Coding}

Coding adalah memberikan kode pada setiap data yang telah diperoleh kedalam bentuk angka untuk memudahkan peneliti dalam proses mengolah data. Dalam pengkodean penelitian sebagai berikut:

a. Nyeri Persalinan Sebelum

1) Diberi kode 0 apabila skala nyeri persalinan nyeri ringan : skor (1-3)

2) Diberi kode 1 apabila skala nyeri persalinan nyeri sedang : skor (4-6)

3) Diberi kode 2 apabila skala nyeri persalinan nyeri berat : skor (7-10)

b. Nyeri Persalinan Sesudah

1) Diberi kode 0 apabila skala nyeri persalinan nyeri ringan : skor (1-3)

2) Diberi kode 1 apabila skala nyeri persalinan nyeri sedang : skor (4-6)

3) Diberi kode 2 apabila skala nyeri persalinan nyeri berat : skor $(7-10)$

\section{c. Entry Data}

Setelah semua jawaban dari masingmasing responden yang dalam bentuk kode (angka atau huruf) dimasukkan dalam program atau software computer. Maka pemprosesan data dilakukan dengan cara mengentry data dari angket ke program SPSS.

\section{Cleaning}

Cleaning dilakukan untuk memastikan bahwa keseluruhan data sudah di entry dan tidak terdapat kesalahan dalam memasukkan data sehingga siap untuk di analisis.

\section{Tabulating}

Tabulating adalah kegiatan untuk meringkas data yang diperoleh kedalam tabel-tabel yang telah disiapkan. Data yang diperoleh kemudian dikelompokkan dan diproses dengan menggunakan table tertentu. Tabulasi data dalam penelitian ini menggunakan system komputer. 


\section{Analisis Data}

\section{Analisis univariat}

Analisis ini bertujuan untuk melihat gambaran distribusi frekuensi setiap variabel yang diteliti, meliputi variabel dependent nyeri persalinan kala I fase aktif dan variabel independent effleurage massage karena variable ini merupakan gambaran dari subjek penelitian sebelum dilanjutkan pada analisis bivariat.

\section{Analisis bivariat}

Analisis bivariate bertujuan untuk mempelajari antara 2 variabel yaitu variable independen dengan variable dependen. Uji statistic yang digunakan adalah Uji T-Test dengan ketentuan Uji T-Test:

a. Jika nilai sig (2-tailed) $<0.005$ maka terdapat perbedaan yang signifikan antara hasil sebelum dan sesudah melakukan effleurage massage

b. Jika nilai sig (2-tailed) > 0.005 maka terdapat perbedaan yang signifikan antara hasil sebelum dan sesudah melakukan effleurage massage

\section{HASIL DAN PEMBAHASAN Kualitas Data}

Berdasarkan tujuan penelitian yaitu untuk mengetahui pengaruh effleurage massage terhadap nyeri kala I fase aktif diPraktik Mandiri Bidan Nuriman Rafida dan Praktik Bidan Mandiri Latifah Kota Jambi. Analisis dari penelitian ini dilakukan dengan dua cara yaitu analisis univariat dan analisis bivariat. Pada analisis univariat akan dilihat frekuensi dan pada analisis bivariat akan dilihat pengaruh antara variabel independen dan variabel dependent. Didapat hasil responden 30 responden pada kelompok eksperimen atau kasus yang diberikan perlakuan effleurage massage tanpa menggunakan kelompok pembanding atau control.

\section{Hasil Penelitian \\ Gambaran effleurage massage terhadap nyeri kala I fase aktif}

Tingkat nyeri responden sebelum dilakukan massage diperoleh dengan cara mengamati atau mengobservasi perilaku responden saat ada kontraksi pada kala I fase aktif pembukaan serviks 4-10 cm dengan menggunakan lembar observasi. Pengamatan dilakukan selama 30 menit pada saat terjadinya kontraksi dengan mengajarkan responden relaksasi nafas.

Dari analisis deskriptif untuk tingkat nyeri responden sebelum dilakukan effleurage massage diperoleh hasil bahwa tidak ada satu pun responden yang merasakan nyeri ringan, terdapat 16 (53\%) responden yang merasakan nyeri sedang, 14 (47\%) responden mengalami nyeri berat. Untuk lebih jelasnya dapat dilihat pada tabel 1 .

Tabel 1. Distribusi responden berdasarkan Nyeri kala I fase aktif sebelum effleurage massage

\begin{tabular}{|c|c|c|c|c|}
\hline \multirow[t]{2}{*}{ No } & \multirow[t]{2}{*}{ Nyeri Kala I Fase Aktif } & \multicolumn{2}{|c|}{ Sebelum } & \multirow[t]{2}{*}{ Mean } \\
\hline & & f & $\%$ & \\
\hline 1 & Ringan & 0 & 0.0 & 6.27 \\
\hline 2 & Sedang & 16 & 53.3 & \\
\hline 3 & Berat & 14 & 46.7 & \\
\hline & Jumlah & 30 & 100.0 & \\
\hline
\end{tabular}

Berdasarkan tabel 1 dapat diketahui bahwa sebelum melakukan effleurage massage sebagian besar responden mengalami nyeri sedang kala I fase aktif sebanyak 16 (53\%) responden dengan skor rata-rata nyeri kala I fase aktif adalah 6.27.

\section{Gambaran effleurage massage terhadap nyeri kala I fase aktif}

Gambaran tingkat nyeri responden yang diperoleh dengan cara mengamati atau mengobservasi respon nyeri responden setelah dilakukan massage selama 20 menit sewaktu terjadinya kontraksi pada kala I fase aktif pembukaan serviks 4-10 cm dengan menggunakan lembar observasi. Massage dilakukan dengan usapan yang lembut, ringan dan terus menerus pada daerah abdomen ibu.

Berdasarkan hasil penelitian diperoleh tingkat nyeri responden mengalami penurunan setelah dilakukan massage, dimana untuk nyeri ringan dirasakan oleh 17 (57\%), 10 responden (33.0\%) merasakan nyeri sedang, dan nyeri berat sebanyak 3 responden (10\%). Dari hasil analisis tersebut diketahui bahwa setelah massage masih ada beberapa responden yang merasakan nyeri berat. Untuk lebih jelasnya dapat dilihat pada tabel 2 berikut ini:

Tabel 2. Distribusi responden berdasarkan Nyeri kala I fase aktif sesudah effleurage massage

\begin{tabular}{|c|c|c|c|c|}
\hline \multirow[t]{2}{*}{ No } & \multirow[t]{2}{*}{ Nyeri Kala I Fase Aktif } & \multicolumn{2}{|c|}{ Sesudah } & \multirow[t]{2}{*}{ Mean } \\
\hline & & f & $\%$ & \\
\hline 1 & Ringan & 17 & 57.0 & 4.17 \\
\hline 2 & Sedang & 10 & 33.0 & \\
\hline 3 & Berat & 3 & 10 & \\
\hline & Jumlah & 30 & 100.0 & \\
\hline
\end{tabular}

Berdasarkan tabel 2 dapat diketahui bahwa setelah melakukan effleurage massage sebagian besar responden mengalami penurunan nyeri kala I dari berat ke sedang dan sedang keringan, setelah melakukan effleurage massage sebagian besar responden mengalami penurunan nyeri kala I yang ringan sebanyak17 (57\%) responden dan skor rata-rata nyeri kala I adalah 4.17. 


\section{Pengaruh effleurage massage terhadap nyeri kala I fase aktif}

Berdasarkan hasil penelitian untuk mengetahui pengaruh effleurage massage terhadap respon nyeri persalinan responden sebelum dilakukan massage dan setelah dilakukan massage dapat dilihat pada table berikut ini:

Tabel 3. Distribusi pengaruh nyeri responden sebelum dan sesudah dilakukan effleurage massage

\begin{tabular}{cccccc}
\hline No & Intervensi & Mean & SD & SE & P $(\boldsymbol{P}$ Value $)$ \\
\hline 1. & Pre massage & 6,27 & 1,363 & 0,249 & \\
2. & Post massage & 4,17 & 1,621 & 0,296 & 0,000 \\
\hline
\end{tabular}

Tabel diatas menggambarkan pengaruh respon nyeri persalinan kala I fase aktif sebelum dilakukan effleurage massage dan setelah dilakukan effleurage massage. Rata-rata nyeri sebelum effleurage massage adalah 6,27 dengan standar deviasi 1,363. Sedangkan pada nyeri setelah effleurage massage terlihat nilai mean sebesar 4,17 dengan standar deviasi1,621. Hasil akhirnya diperoleh $\mathrm{t}=11,987$ dan $P($ value $)=0,000$.

Hasil uji statistic pada alpha 0,05 didapatkan $p$ value $0,000 \quad(p<0,05)$ yang berarti ada perbedaan signifikan antara nyeri sebelum massage dengan setelah massage, dengan kata lain jika dilakukan effleurage massage dapat menurunkan nyeri. Sehingga dari hasil analisis ini dapat ditarik kesimpulanya itu ada pengaruh effleurage massage terhadap nyeri kala I fase aktif.

\section{Keterbatasan Penelitian}

Penelitian ini merupakan penelitian dengan menggunakan jenis penelitian kuantitatif quasi eksperimental design, dengan rancangan yang digunakan adalah pretest posttest one grup design untuk melihat pengaruh effleurage massage terhadap nyeri kala I fase aktif di Praktik Mandiri Bidan Nuriman Rafida dan Praktik Bidan Mandiri Latifah Kota Jambi Tahun 2019.

Dari segi teknis tidak ada kendala yang begitu berarti selama penelitian, hanya saja dalam pelaksanaannya kesulitan yang dirasakan adalah keterbatasan tenaga karena harus membagi waktu di 2 tempat penelitian sehingga jumlah sampel yang diperoleh kurang maksimal. Berhubung karena keterbatasan waktu itu pula yang membuat peneliti tidak membedakan atau mengelompokkan responden berdasarkan paritas, primipara, atau multipara. Sehingga hasil yang diperoleh merupakan hasil secara umum, tidak secara spesifik mengungkap perbedaan tingkatan nyeri maupun respon nyeri responden berdasarkan paritas.

Secara teoritis terdapat 2 teknik massage yang dapat dilakukan oleh bidan atau pendamping persalinan untuk membantu mengendalikan nyeri persalinan kala I fase aktif yaitu teknik effleurage dan counterpressure, tetapi karena keterbatasan waktu, pengetahuan dan tenaga maka penelitian ini hanya meneliti dari teknik effleurage massage.

\section{Pembahasan}

Gambaran Tingkat Nyeri Responden Sebelum Dilakukan Effleurage Massage Terhadap Nyeri Kala I Fase Aktif

Gambaran nyeri persalinan sebelum effleurage massage diperoleh hasil (53\%) dari responden mengalami rasa nyeri sedang, dimana pada umumnya secara objektif responden mendesis, menyerengai, dapat menunjukan lokasi nyeri dengan tepat dan dapat mendeskripsikan nyeri, klien dapat mengikuti perintah dengan baik. Selebihnya responden merasakan nyeri berat. Tidak ada satupun responden yang merasakan nyeri persalinan sebagai nyeri yang ringan sebelum massage.

Sesuai dengan teoriTelfer (1997) dalam Fraser \& Cooper (2009:461) bahwa nyeri persalinan merupakan fenomena multi factorial yang subjektif, personal, dan kompleks yang dipengaruhi oleh factor psikologis, biologis, social budaya dan ekonomi. Maka wajar bila tingkatan nyeri yang dirasakan pada tiap responden berbeda-beda sesuai dengan faktor yang mempengaruhinya.

Pada responden yang mengalami nyeri berat pada umumnya adalah responden dengan persalinan anak pertama (primipara). Hal ini dapat dipahami karena pada primipara ini merupakan pengalaman pertama mereka dalam melahirkan, sehingga kadang timbul ketakutan dan kecemasan yang dapat merangsang keluarnya hormone stress dalam jumlah besar yang mengakibatkan timbulnya nyeri persalinan yang lama dan lebih berat.

\section{Gambaran Tingkat Nyeri Responden Sesudah Dilakukan Effleurage Massage Terhadap Nyeri Kala I}

Berdasarkan hasil analisa data diperoleh gambaran nyeri persalinan setelah di massage yaitu sebagian dari responden merasakan nyeri ringan (57\%), selebihnya merasakan nyeri sedang dan nyeri berat.

Dengan demikian dapat dinyatakan bahwa effleurage massage dapat menutup gerbang atau menghambat impuls nyeri sehingga hanya sedikit rasa nyeri yang dihantarkan ke system saraf pusat.Hal ini sesuai dengan teori yang menyatakan bahwa effleurage massage merupakan salah satu metode penanggulangan nyeri non farmakologi untuk mengurangi atau meringankan nyeri kala I. Ketika sentuhan dan nyeri dirangsang bersama, sensasi sentuhan berjalan ke otak menutup pintu gerbang dalam otak. Dengan adanya pijatan atau sentuhan yang mempunyai efek distraksi juga dapat meningkatkan pembentukan endorphin dalam system control desenden dan membuat relaksasi otot.

Massage dan sentuhan yang dilakukan pada ibu bersalin kala I fase aktif terbukti dapat membantu ibu lebih rileks dan nyaman selama persalinan. Setelah dilakukan effleurage massage responden merasakan nyeri ringan dan hanya beberapa responden yang merasakan nyeri sedang dan nyeri berat. 
Hal ini dapat dipahami karena responden yang merasakan nyeri berat tersebut adalah responden yang sebelum massage merasakan nyeri pada tingkat yang sangat berat, dan umumnya adalah responden dengan persalinan anak pertama dengan usia muda, sehingga setelah dilakukan effleurage massage tingkat nyeri berat tersebut berhasil diturunkan pada skala nyeri sedang.

\section{Pengaruh Effleurage Massage Terhadap Nyeri Persalinan Kala I Fase Aktif}

Berdasarkan hasil penelitian dan analisis dari data pengaruh effleurage massage terhadap nyeri persalinan kala I fase aktif diperoleh hasil bahwa rata-rata nyeri responden mengalami penurunan setelah dilakukan massage. Hal ini membuktikan bahwa effleurage massage dapat menurunkan respon nyeri persalinan dari skala nyeri berat menjadi nyeri sedang dan skala nyeri sedang menjadi nyeri ringan.

Secara statistic ada perbedaan yang signifikan dengan nilai sig (2-tailed) hitung $0.000<0.05$ maka dapat disimpulkan bahwa terdapat pengaruh yang signifikan antara effleurage massage terhadap nyeri kala I fase aktif di Praktik Mandiri Bidan Nuriman Rafida dan Praktik Bidan Mandiri Latifah Kota Jambi Tahun 2019.

Sebuah penelitian menyebutkan ibu yang dipijat selama 20 menit setiap jam selama tahapan persalinan akan lebih bebas dari rasa sakit, karena pijat merangsang tubuh melepaskan senyawa endorphin yang merupakan pereda sakit alami dan menciptakan perasaan nyaman dan enak.

Sesuai dengan pernyataan Mander (2003:164) bahwa tindakan utama massage dianggap 'menutup gerbang' untuk menghambat perjalanan rangsang nyeri pada pusat yang lebih tinggi pada system saraf pusat. Selanjutnya rangsangan taktil dan perasaan positif yang berkembang ketika dilakukan bentuk sentuhan yang penuh perhatian dan empatik bertindak memperkuat efek massage untuk mengendalikan nyeri. Dukungan emosional dalam menghadapi persalinan akan menimbulkan perasaan senang yang akan menjadi impuls ke neurotransmitter ke system limbic kemudian diteruskan ke amigdala lalu dibawa ke hipotalamus sehingga terjadi perangsangan pada nucleus ventromedial dan area sekelilingnya yang dapat menimbulkan perasaan tenang (Guyton, 2007).

Menurut Penelitian Nila Qurniasih (2017) hasil analisis regresi logistik menunjukkan bahwa effleurage massageberpengaruh terhadap penurunan intensitas nyeri persalinan setelah di kontrol dengan variabel persalinan. ibu yang memperoleh effleurage massagepada kala I fase aktif berpeluang mengalami nyeri sedang sebesar 3,45 dibandingkan dengan ibu yang mendapatkan perawatan standar. Penelitian Handayani (2011) dengan judul Pengaruh Effleurage Massage Terhadap Nyeri Primipara Kala I Persalinan Fisiologis di RSIA Bunda Arif Purwokerto membuktikan bahwa effleurage massagedapat mengurangi nyeri dari skala 7,647 menjadi 6,117.

Berdasarkan penelitian di ketahui bahwa dalam persalinan massage bukan hanya sekedar memberikan sentuhan fisik semata tetapi juga membuat ibu merasa lebih dekat dengan orang yang merawatnya dan merasa lebih diperhatikan. Sentuhan seseorang yang peduli dan ingin menolong disertai komunikasi yang baik merupakan sumber kekuatan ibu saat sakit, lelah dan takut. Sehingga alangkah baiknya jika setiap ibu bersalin memperoleh informasi yang cukup mengenai metode pengendalian nyeri baik secara farmakologis dan non farmakologis.

\section{SIMPULAN}

Berdasarkan hasil penelitian dan analisis tentang pengaruh effleurage massage terhadap nyeri kala I fase aktif di Praktik Mandiri Bidan Nuriman Rafida dan Praktik Bidan Mandiri Latifah Kota Jambi Tahun 2019, maka dapat ditarik kesimpulan sebagai berikut:

1. Sebelum dilakukan effleurage massage sebagian besar $16(53 \%)$ responden merasakan nyeri sedang, $14(47 \%)$ merasakan nyeri berat dan tidak ada responden yang merasakan nyeri ringan.

2. Setelah dilakukan effleurage massage terjadi penurunan respon nyeri persalinan kala I fase aktif didapatkan sebagian besar $(57.0 \%)$ responden merasakan nyeri ringan, masih sebagian (33\%) responden yang merasakan nyeri sedang, dan hanya sebagian kecil (10\%) responden yang merasakan nyeri berat kemungkinan karena ibu dengan primipara belum memiliki pengalaman dalam melahirkan, sehingga kadang timbul ketakutan dan kecemasan yang dapat merangsang keluarnya hormone stress dalam jumlah besar yang mengakibatkan timbulnya nyeri persalinan yang lama dan lebih berat.

3. Terdapat pengaruh yang signifikan antara effleurage massage terhadap penurunan nyeri kala I fase aktif di Praktik Mandiri Bidan Nuriman Rafida dan Praktik Bidan Mandiri Latifah Kota Jambi Tahun 2019 dengan $P$ (value) $0.000<0.05$

\section{DAFTAR PUSTAKA}

Aprillia, Yessie. 2011. Siapa Bilang Melahirkan itu Sakit. Yogyakarta: C.V Andi

Artanty Nisman, Wenny.2011. Ternyata Melahirkan itu Mudah dan Menyenangkan. Yogyakarta : C.V Andi

Cooper, Fraser. 2009. Buku Ajar Bidan Myles. Jakarta: ECG

Evariny Andriana. 2007. Melahirkan Tanpa Rasa Sakit. Jakarta: PT. Bhuana IImu Populer

Fatmawati, Lis. 2011. Pengaruh Teknik Relaksasi Pernafasan Terhadap Tingkat Rasa Nyeri Pada Ibu Bersalin Kala I di BPS Mu'rofah, Amd. Keb. Universitas Muhammadiyah Surabaya. http://www.google.com=pengaruh+relaksasi+pern afasan+terhadap+tingkat+rasa+nyeri+pada+ibu+b ersalin+kala+l=kti.kebidanan.files. wordpress.com. 22/01/2019

Ghofur, Abdul. 2010. Pengaruh Teknik Relaksasi Nafas Dalam Pada Pasien Inpartu kala I Fase Laten di Rumah Bersalin Depok Jaya. Universitas Pembangunan Nasional Veteran Jakarta. http://www.google.com=pengaruh+relaksasi+nafa s+terhadap+respon+adaptasi+nyeri+dalam+pada +inpartu+kala+l+fase+laten=skripsistikes. files. wor dpress.com. 25/01/2019 
Indrayani, dkk. 2016. Asuhan Persalinan dan Bayi Baru Lahir. Jakarta : CV. Trans Info Media

Judha, Mohammad. 2012. Teori Pengukuran Nyeri dan Nyeri Persalinan. Yogyakarta: Nuha Medika

Kementrian Kesehatan Republik Indonesia. 2017. Profil Kesehatan Indonesia Tahun 2017

Manuaba. 2009. Memahami Kesehatan Reproduksi Wanita. Jakarta: Buku Kedokteran EGC

Mohamad, Judha dkk. 2009. Teori Pengukuran Nyeri. Nuha Medika. Yogyakarta

M.T. Indiarti. 2015. Panduan Persiapan Kehamilan, Kelahiran \& Perawatan Bayi. Yogyakarta : Parama IImu

Ningtyas. 2009. Asuhan Keperawatan Persalinan Normal. Jakarta: Salemba Medika

Nolan, Mary. 2015. Panduan Komprehensif tentang Kehamilan Sehat. Yogyakarta : Golden Books

Prawirohardjo, Sarwono. 2009. Teori Pengukuran Nyeri. PT, Bina Pustaka Sarwono Prawirohardjo. Jakarta

Prasetyo, Sigit Nian. 2010. Konsep Dan Proses Keperawatan NyeriEdisi I Cetakan I. Yogyakarta: Graha IImu

Rohani, S.ST, dkk. 2011. Asuhan Kebidanan Pada Masa Nifas. Jakarta : Salemba Medika

Sumarah At Al. 2010. Perawatan Ibu Bersalin (Asuhan Kebidanan Pada Ibu Bersalin) Cetakan V. Yogyakarta: Fitramaya

Varney, Hellen. 2007. Buku Ajar Asuhan Kebidanan. Jakarta: ECG

Wiknjosastro, Hanifa. 2007. IImu Kebidanan Edisi III Cetakan IX. Jakarta: Yayasan Bina Pustaka Sarwono Prawirohardjo 